\title{
HILANGNYA ETIKA SEBAGAI SARANA ORIENTASI DAN KEBEBASAN EKSISTENSIONAL ELIT POLITIK
}

\author{
Samuel Jusuf Litualy
}

Email: samly_56@yahoo.co.id

Jurusan Bahasa dan Seni FKIP Universitas Pattimura Ambon

Alamat Korepondensi: Jalan Tabeajou, G. Kharisma RT. 002/04 Kel. Waihoka Karang Panjang Ambon 97128

\begin{abstract}
Bertold Brecht's anecdote If Sharks Were Men tells us about the life in the sea between sharks and little fish. Sharks teach the little fish about moral and their obedience to sharks. If they always obey to the sharks, they will have better future. This anecdote describes the political elite as sharks. They are being described as people, who are thirst of authority, but on the other side teach the ordinary people about "moral". The ordinary people are being described as little fishes, that can be easily influenced and dominated. In this work, Brecht places himself as Mister K, the narrator, who lucidly describes the character of the ruler or political elite and the ordinary people. He makes three important points as a reflection of the life at that time. Firstly, the political elite always use the other people for their personal and group interest without feeling guilty, or in other words, public deception has already become a trend for political elite. Secondly, the ordinary people can be easily influenced to follow what Brecht calls in his work as "moral teaching". Thirdly, the character of political elite always deceive and ignore the people and the helplessness of the people in dealing with the ruler is seen in this work as a reflection of the loss of ethics as an orientation and of their powerlessness in enjoying their existential freedom.
\end{abstract}

\section{Keywords}

Anekdot, Etika, Orientasi, Eksistensional

\section{Pendahuluan}

Pengertian anekdot (dalam Kamus Besar Bahasa Indonesia terbitan Prima Pena) adalah cerita sederhana atau singkat yang lucu dan bersifat mengkritik. Sementara itu, di dalam Duden (Deutsches Universal Wörterbuch) dijelaskan bahwa anekdote adalah cerita pendek, yang umumnya lucu, namun mengkritik, yang menggambarkan tentang sifat atau karakter seseorang, kelompok masyarakat pada masa tertentu.

Berdasarkan pengertian tersebut, maka dapat dijelaskan bahwa ciri-ciri karya anekdot adalah singkat (umumnya hanya terdiri dari satu halaman), bersifat menggelitik (lucu), dan mengandung pesan/kritik.

Pengisahan dalam anekdot umumnya tidak jauh berbeda dengan pengisahan dalam cerpen (cerita pendek), namun dalam anekdot ada beberapa unsur, seperti: tokoh dan setting (latar) sering disamarkan. Umumnya tokoh dalam anekdot adalah berupa hewan (baik di darat maupun di laut). Dengan demikian, maka latar cerita tentu disesuaikan dengan habitat tokoh yang disamarkan. Penyamaran tokoh dan latar dalam anekdot oleh penyair bertujuan untuk mengamankan diri dan sekaligus menjamin kebebasannya dalam menyalurkan aspirasinya melalui karyanya.

Sebagai salah satu karya sastra, anekdot disajikan dalam bentuk kisah atau cerita yang mengkritik, dan dibumbui atau diselingi dengan cerita-cerita yang lucu dan menggelitik, namun sebenarnya mengandung pesan atau peringatan yang pedas/keras. Cerita anekdot ditujukan kepada orang-orang atau tokoh-tokoh yang memiliki kuasa, namun karena sifatnya yang hanya mementingkan diri dan kelompoknya sendiri, menyebabkan timbulnya permasalahanpermasalahan yang terjadi di dalam masyarakat.

Di dalam sosiologi sastra diungkapkan bahwa sastra merupakan cerminan kehidupan masyarakat, sebab melalui karya sastra pengarang mengungkapkan problema kehidupan masyarakat di sekitarnya. Menurut Mudji Sutrisno (1995: 2, 4-6), secara historis karya sastra selalu terkait erat dengan masyarakat 
karena karya sastra merupakan suatu karya yang menggunakan bahasa tersendiri, yakni bahasa ekspresif yang isinya mencakup lingkup kehidupan manusia. Karya sastra tidak pernah sepi dari menyuarakan kenyataan sehari-hari, dan mengajak masyarakat untuk memahami tragedi-tragedi sosial dan politik tentang kemanu-siaan, seperti kemelaratan, kelaparan, penindasan, pergolakan politik, konflik kemanusiaan, kekejian perang (pengabaian harga diri manusia), dan sebagainya atau dengan perkataan lain karya sastra selalu mengabdi pada kemanusiaan. Ungkapan tersebut lebih mempertegas adanya realisme dalam karya sastra yang juga berarti karya sastra mengandung realita dalam masyarakat. Realisme dalam sastra menjanjikan pembebasan bagi sastrawan dan masyarakat dari belenggu penindasan (Ananta Toer, 2003: 5).

Para sastrawan mengungkapkan berbagai fenomena sosial melalui berbagai karya sastra yang dikemas dalam nilai estetis yang tinggi. Pentingnya estetika atau keindahan dalam karya sastra dikemukakan oleh Ruttkowsky (1974: 124), bahwa Faktor estetika dalam anekdote dan karya sastra lainnya lebih penting dari pada logikanya, emosi lebih berperan dari pada ratio, dan yang sering terjadi adalah perasaan dan pengalaman hidup penulis mewarnai karyanya. Meskipun demikian para sastrawan harus tegas dan berani dalam mengemukakan fakta-fakta seperti apa adanya sehingga masyarakat tidak salah dalam memberikan penilaian.

Salah satu karya sastra yang mencerminkan dan sekaligus mempertegas pendapat di atas, adalah Anekdote karya Bertold Brecht „Wenn die Haifischen Menschen wären" (Seandainya Ikan Hiu adalah Manusia), yang dimuat dalam Deutsch für Mittelstufe karya Schumann (1988: 66-67). Karya ini dikaji dari segi sosiologi sastra, karena permasalahan yang diungkapkan oleh pengarang karya tersebut adalah persoalan sosial, yang ditata dalam bentuk karya sastra.

Anekdote ini ditulis dengan latar kehidupan masyarakat Jerman di era 1930-an. Walaupun waktu penulisannya telah lama berlalu dan letak geografis negara Jerman sangat jauh dari Indonesia, serta adanya perbedaan sosial budaya masyarakat Jerman dan Indonesia, namun inti karya tersebut masih sangat mirip dengan situasi dan kondisi sosial masyarakat Indonesia pada saat ini. Dalam pemilihan umum (baik untuk pemilihan calon legislatif, maupun pemilihan calon presiden) beberapa waktu yang lalu untuk meraih kedudukan dan kekuasaan, para kandidat terkesan mengobral program-program melalui propaganda dan iming-iming masa depan yang lebih baik dan cerah bagi masyarakat kecil, seakan-akan bila mereka terpilih maka segala persoalan yang menjadi pergumulan masyarakat lantas teratasi. Ada juga kandidat yang tidak segan-segan menempuh dan menghalalkan berbagai macam cara dan berusaha untuk mempengaruhi masyarakat dengan berbagai slogan yang kedengarannya indah dan menarik, namun sangat membahayakan di kemudian hari, bahkan ada yang secara terang-terangan mengorbankan masyarakat kecil demi pencapaian tujuan mereka. Brecht mengemukakan berbagai fenomena sosial yang terjadi pada saat itu melalui karya anekdotenya „Seandainya Ikan Hiu adalah Manusia“ yang ditata dalam nilai keindahan (estetis) yang tinggi tanpa mengorbankan kenyataan di sekelilingnya. Pengarang berusaha sebebas-bebasnya ke luar dari keterbelengguan, berani mengemukakan fakta seperti apa adanya dengan tujuan agar masyarakat pembaca ikut mengetahui apa yang sedang terjadi di sekeliling mereka, sehingga tidak keliru dalam memberikan penilaian.

Brecht dalam anekdot tersebut mengisahkan tentang Tuan $\mathrm{K}$ (orang ketiga) sebagai penjawab pertanyaan si gadis kecil, ingin membeberkan fenomena yang merupakan pelanggaran terhadap etika sebagai sarana orientasi dan kebebasan eksistensional yang seharusnya terdapat dalam diri orang-orang yang tergolong dalam kategori baik. Apalagi sebagai elit politik (penguasa) mestinya memiliki etika dan moral yang luhur, yang berkewajiban menegakkan kebenaran, melindungi dan menjamin hak hidup (kebebasan eksistensional) masyarakat kecil pendukungnya.

Walaupun etika berbeda dengan moral, namun dalam membicarakan etika selalu dikaitkan dengan moral, sedangkan kebebasan eksistensional merupakan kemampuan manusia menentukan dirinya sendiri, yakni bebas dari rasa takut, tekanan, dan pengaruh lainnya (Magnis Suseno: 1987: 14, 23). Dengan demikian maka kajian utama tulisan ini adalah tentang hubungan watak para tokoh dalam anekdote ini dengan etika sebagai sarana orientasi dan kebebasan eksistensional, khususnya yang berhubungan dengan situasi sosial politik.

\section{Etika Sebagai Sarana Orientasi dan Kebebasan Eksistensional}

Telah dikemukakan sebelumnya bahwa dalam membicarakan etika selalu dikaitkan dengan moral. Kedua istilah ini perlu dibahas agar jelas perbedaannya. Menurut Julian Baginni (2003: 45) etika merupakan studi tentang perilaku manusia. Apa yang sesungguhnya dilakukan orang bukanlah etika, melainkan apa yang 
seharusnya dilakukan. Sebaliknya moral merupakan bagian dari etika. Norma moral merupakan sejumlah aturan yang mengikat dan menen-tukan bagaimana seharusnya orang berperilaku. Pendapat Baginni di atas sekaligus memberikan batasan dan membedakan substansi kedua terminologi yang sebenarnya berbeda namun memiliki kaitan yang sangat erat. Perbedaan kedua istilah terletak pada apa dan bagaimana. Etika berkaitan dengan apa yang seharusnya dilakukan, sedangkan moral berkaitan dengan aturan-aturan tentang bagaimana berperilaku. Atau dengan kata lain moral berkaitan de-ngan norma-norma yang diterima secara universal di dalam masyarakat

Menurut Magnis Suseno (1987:14, 23), etika dipandang sebagai sarana orientasi bagi usaha manusia untuk menjawab suatu pertanyaan yang fundamental: bagai-mana saya harus hidup dan bertindak? Dalam hubungan dengan pertanyaan ini, jawaban dapat diperoleh dari banyak pihak, seperti orang tua, guru, adat istiadat dan tradisi, teman, lingkungan sosial, agama, negara, dan sebagainya. Yang menjadi persoalan adalah apakah benar apa yang mereka katakan? Dan bagaimana kalau mereka masing-masing memberikan jawaban yang berlainan? Lalu jawaban mana yang harus diikuti? Dalam situasi yang sangat membingungkan ini, etika dapat memainkan peranannya. Dalam hal ini etika dapat membantu untuk mencari orientasi yang bertujuan agar orang tidak hidup dengan cara ikut-ikutan pada pihak-pihak yang ingin mengatur dan menetapkan bagaimana orang harus hidup, melainkan agar orang dapat memahami sendiri mengapa orang harus bersikap dan bertindak begini atau begitu. Etika membantu orang agar lebih mampu mempertanggungjawabkan kehidupannya.

Di dalam kehidupan berbangsa dan bermasyarakat di Indonesia saat ini banyak sekali terlihat adanya penyalahgunaan wewenang dan terjadinya banyak sekali penyimpangan terhadap norma atau aturan-aturan universal. Hal ini menandakan bahwa etika dan moral di negeri ini belum dijalankan sebagaimana seharusnya.

Sebagai sarana orientasi, seringkali etika telah ditetapkan secara tepat, namun di dalam pelaksanaannya orang seringkali terjebak dalam ikatan pemikiran atau kepentingannya, sehingga terpaksa melanggar etika yang telah ditetapkan. Banyak persoalan kemanusiaan (HAM) yang terjadi di negeri ini yang tidak pernah terselesaikan merupakan contoh adanya kaitan belenggu kepentingan banyak pihak, yang menyebabkan pengabaian terhadap etika dan moral.
Berdasarkan pengertian etika dan moral yang dikemukakan di atas, dapat disimpulkan bahwa etika berhubungan dengan apa yang harus dilakukan seseorang ketika menghadapi masalah, sedangkan moral berkaitan dengan bagaimana cara melakukan keputusan yang telah ditetapkan dan mengapa demikian.

Kemampuan seseorang untuk mengambil keputusan terhadap sesuatu hal dan didasarkan pada pertimbangan sendiri, serta berkaitan dengan kebebasan dan tanggung jawabnya sendiri dalam menentukan sikap dan tindakannya dikenal dengan istilah kebebasan eksistensional (Suseno: 1987: 33). Kebebasan eksistesional ini ditunjang dengan moral yang mandiri (otonomi moral) di mana seseorang melakukan sesuatu karena dia menyadari sendiri nilai dan tanggung jawab yang ada di dalam dirinya. Sebaliknya sikap di mana seseorang memenuhi kewajibannya bukan karena dia bebas menentukannya tetapi karena adanya tekanan, ancaman, dan karena rasa takut, dan sebagainya merupakan moral tidak bebas (heteronomi moral). Kebebasan eksistensional dengan moral mandiri tentu dapat dipertanggungjawabkan.

Dewey, yang dikutip Watloly (2001: 104) mengemukakan bahwa moralitas yang mandiri (otonom) tidak hanya untuk diketahui atau dikenal secara akal tetapi lebih dari pada itu. Moralitas sangat terkait dengan pengalaman, teristimewa dalam rangka membuat atau mengambil keputusan-keputusan. Dengan pengertian bahwa persoalan tanggung jawab bukan sekedar berarti bahwa apa yang telah kita putuskan jangan dibebankan kepada orang lain, melainkan kita harus bertanggungjawab atas segala akibat yang ditimbulkan oleh keputusan itu. Dengan demikian, kebebasan eksistensional tidak boleh diartikan sebagai kebebasan untuk melakukan apa saja secara semena-mena melainkan kebebasan eksistensional adalah kebebasan yang bertanggungjawab.

Persoalan kebebasan yang bertanggungjawab ini dalam kenyataannya belum terjadi di dalam masyarakat kita sekarang ini. Masyarakat kecil kita selalu dijadikan alat untuk kepentingan para elit politik (penguasa), selalu dikorbankan, ditempatkan sebagai umpan digaris depan, selalu dijadikan tameng. Untuk itu, maka perlu dipertanyakan: apakah di dalam masyarakat kita sudah terwujud kebebasan eksistesional, atau apakah ada moral otonom di dalam masyarakat? Dengan pertanyaan lain apakah masyarakat melakukan segala sesuatu dalam hidup mereka atas dasar kesadaran mereka sendiri terutama dalam memanfaatkan kebebasan eksistensional mereka? Banyak fakta yang terjadi di sekeliling 
kita, di mana masyarakat kecil selalu dikorbankan, masyarakat kecil selalu digaris depan, masyarakat kecil tidak bebas menentukan sendiri keputusannya karena takut pada tekanan, dan sebagainya. Karena itu, idealisme adanya etika sebagai sarana orientasi yang di dalamnya diatur kebebasan eksistensional, semata-mata hanya merupakan slogan para penguasa (elit politik). Dalam hubungan ini, Sartre mengemukakan pengalaman fundamentalnya, yakni kebebasan (diri sebagai "subjek" dan benda sebagai "objek") yang merupakan simbol kondisi manusia termasuk di dalamnya para penguasa dan elit politik, yang di satu pihak mengalami dirinya sebagai makhluk bebas, namun di lain pihak selalu dihadapkan pada kuasa dan daya tarik benda (kekayaan) (Abidin, 2003: 173).

Menetapkan atau mengambil suatu keputusan karena takut dikucilkan atau karena berada di bawah tekanan merupakan indikator bahwa moral yang tumbuh dan berkembang pesat saat ini di dalam masyarakat adalah moral heteronom. Atau dengan perkataan lain, masyarakat kita adalah masyarakat yang memiliki moral heteronom. Dalam kaitan dengan kenyataan di atas dapat dianggap bahwa telah terjadi penyimpangan moral di dalam masyarakat kita saat ini.

Apa yang diibaratkan Brecht melalui karya anekdotnya ini mencerminkan moral politik para elit politik (penguasa). Pada satu sisi para elit politik merasa tanpa berdosa memanfaatkan masyarakat kecil atau mengatasnamakan masyarakat kecil untuk berbagai kepentingannya, dengan berbagai janji dan slogan yang mulukmuluk yang oleh Brecht disebut sebagai Theater (sandiwara). Pada sisi lain, masyarakat kecil terlalu mudah percaya pada perkataan-perkataan dan janji-janji kosong para elit politik (penguasa), yang pada kenyataannya justru mengorbankan masyarakat untuk kepentingannya. Dari kenyataan ini, tampak jelas bahwa masyarakat kita sangat labil dalam bertindak dan tidak atau belum memiliki etika sebagai sarana orientasi dan kebebasan dalam mengambil keputusan.

Ada pesan moral yang cukup jelas yang diungkapkan Brecht melalui karya anekdote "wenn die Haifischen Menschen wären" (Seandainya ikan hiu adalah manusia). Di dalam karya ini Brecht berusaha menggugah para pembaca untuk membuat perenungan atas apa yang mereka lakukan selama ini, dan apa yang menjadi tanggung-jawab mereka. Secara tidak langsung Brecht mau mengajak para pembaca bahwa sifat patuh dan rela berkorban yang dikisahkan dalam anekdotnya boleh mereka lakukan, namun harus dilakukan atas dasar keputusan diri sendiri dan dapat dipertanggungjawabkan sebagai wujud dari kebebasan eksistensional yang melekat pada diri setiap orang. Bukan karena dipengaruhi dan diiming-imingi dengan harta atau kekuasaan, apalagi dipaksa oleh orang lain. Dengan kata lain, keputusan yang diambil adalah keputusan yang rasional bukan emosional.

Dalam kaitan ini, para pembaca diajak untuk berorientasi atau berkiblat pada penggunaan kebebasan eksistensional dan otonomi moral yang dimilikinya secara bertanggung jawab. Brecht ingin mendorong pembacanya untuk membuat perenungan atas eksistensi atau keberada-annya sebagai manusia yang diciptakan untuk menjalankan kebebasannya secara bertanggungjawab. Perenungan diri manusia kadang-kadang dilupakan atau bahkan diabaikan, karena semakin sibuknya manusia sejalan dengan makin pesatnya kemajuan dan menumpuknya kebutuhan jasmani yang harus segera diusahakan pemenuhannya.

Dalam kaitannya dengan keadaan tersebut, Hardono Hadi (1996: 15) mengemukakan bahwa perkembangan dan kemajuan, serta semakin kompetitifnya manusia dalam mengejar ketertinggalan, membuat manusia tidak sempat merenung dan merefleksi tentang apa dan siapa dirinya. Salah satu penyebab lain, mengapa masyarakat tidak membuat perenungan tentang dirinya adalah karena kesadaran masyarakat tentang kebebasan eksistensional yang dimilikinya masih rendah.

\section{Sinopsis Anekdote Seandainya Ikan Hiu Adalah Manusia}

Seandainya ikan Hiu adalah manusia, akankah mereka ramah terhadap ikan- kecil ? Tanya si gadis kecil pemilik kos kepada Tuan K..... hal utama yang akan dilakukan oleh ikan hiu adalah membentuk moral ikan-ikan kecil. Mereka akan diajarkan bahwa hal yang terbesar dan terindah adalah sifat rela berkorban, dan harus patuh kepada ikan hiu, terutama bila ikan hiu menjanjikan mereka masa depan yang cerah. Ikan-ikan kecil akan diajarkan bahwa masa depan yang cerah hanya akan pasti, jika mereka patuh. Ikan-ikan kecil harus menghindarkan diri terhadap kecenderungan-kecenderungan buruk, seperti materialis, egois, dan marxis. Bila ada ikan kecil yang memiliki kecenderungan ini, ikan kecil lainnya harus segera melaporkannya kepada ikan hiu.Seandainya ikan hiu adalah manusia, tentu akan dikobarkan perang dengan ikan hiu lainnya dan ikan-ikan kecil ditempatkan di garis depan. Ikan-ikan kecil akan dimanfaatkan untuk memerangi ikan-ikan kecil kelompok hiu lainnya. 
Ikan-ikan kecil akan diajarkan bahwa antara ikan-ikan kecil kelompok hiu yang satu sangat berbeda dengan ikan-ikan kecil kelompok hiu lainnya. Ikan-ikan kecil yang berhasil membunuh ikan-ikan kecil lainnya dalam perang dianggap sebagai pahlawan dan memperoleh tanda jasa.

Andaikan ikan hiu adalah manusia, maka akan dihadirkan juga pentas seni. Taring ikan hiu akan diberi lukisan berwarna warni yang menunjukkan kemegahan, mulutnya dijadikan taman bermain, di mana selalu tergambar keceriaan. Teater disuguhkan dengan pelakonnya ikan-ikan kecil yang gagah berani, dengan bunyi musik yang amat indah, sehingga semua ikan kecil turut menikmatinya. Andaikan ikan hiu adalah manusia, di sana pun ada agama. Ikanikan kecil diajarkan untuk tetap hidup dengan nyaman dalam lindungan ikan hiu.

Andaikan ikan hiu adalah manusia, maka semua ikan kecil mendapat perlakuan yang sama. Ada yang beroleh jabatan dan boleh berkuasa atas ikan-ikan kecil lainnya. Yang lebih besar boleh memangsa yang kecil-kecil, sedangkan hanya ikan hiu sendirilah yang boleh memangsa ikanikan besar. Singkatnya, tentu ada budaya di laut, andaikan ikan hiu adalah manusia.

\section{Unsur-unsur Intrinsik dalam Anekdot Seandainya Ikan Hiu adalah Manusia}

Anekdot tersebut memiliki (a) tema, etika dan moral semu penguasa, (b) amanat, menjadikan etika dan moral sebagai sarana orientasi dan kebebasan eksistensional, (c) alur, kronologis, (d) tokoh pencerita/dalang, tuan $\mathrm{K}$, si gadis kecil (tokoh penanya), tokoh dalam cerita: ikan hiu (antagonis), ikan besar, ikan-ikan kecil (protagonis), (e) setting, kehidupan dalam laut.

\section{Hilangnya Etika dan Moral dalam Anekdot Seandainya Ikan Hiu adalah Manusia}

Dalam anekdote di atas, Brecht menempatkan diri sebagai tokoh Tuan K (si pencerita), yang menjawab pertanyaan tokoh si gadis kecil tentang „apa yang akan dilakukan oleh ikan Hiu, seandainya makhluk laut yang terkenal buas dan ganas itu adalah manusia“. Brecht dalam karya anekdote tersebut secara tersirat mengemukakan sikap dan sifat (karakter) khas ikan hiu (Haifische) dan ikan-ikan kecil, namun sebenarnya secara simbolik merujuk pada diri manusia, dalam hal ini lebih merujuk pada elit politik (penguasa) dan masyarakat kecil. Hal ini jelas terlihat ketika Brecht mengemukakan semua kenyataan (fakta) yang ada di alam sekitar manusia, seperti: ikan hiu (Haifischen), ikan kecil (Fischlein), ajaran moral (moralische Ausbildung), agama (Religion), masa depan (Zukunft), perang (Kriege), dan bahasa (Sprache). Sebab tentu saja di dalam dunia makluk hidup yang lain (hewan/binatang) tidak dikenal kebebasan, tanggungjawab, ajaran moral, agama, masa depan, dan bahasa, kecuali pada manusia. Menurut Frans Magnis Suseno (1987: 21), hewan atau binatang tidak mengenal faham kewajiban dan tidak dapat dianggap bertanggungjawab, karena tidak memiliki kebebasan. Apa yang dilakukan hewan, ditentukan oleh insting dan kecondongan-kecondongan alamiah lainnya.

Di dalam Duden dijelaskan bahwa anekdote adalah cerita pendek, yang umumnya lucu, namun mengkritik, yang menggambarkan tentang sifat atau karakter seseorang, kelompok masyarakat pada masa tertentu. Dalam hubungan ini, sebenarnya apa yang dikisahkan Brecht dalam anekdote tersebut berkaitan dengan suasana politik pemerintahan Jerman di tahun 1930-an, di mana salah satu inti doktrin Hitler (sang Führer) adalah kepatuhan pada penguasa (Gehörsamkeit). Brecht dalam anekdote ini menggambarkan sifat-sifat khas penguasa (elit politik) dan masyarakat pada zaman itu, yang diandaikan dengan ikan hiu dan ikan-ikan kecil. Sifat penguasa yang otoriter diibaratkan sebagai ikan hiu (buas/ganas), yang dalam kisah tersebut seolah-olah bermoral tinggi sehingga ingin mengajarkan moral kepada ikan-ikan kecil. Pada kenyataannya sama sekali tidak bermoral, buas atau rakus kekuasaan dan tidak segan-segan memangsa, sedangkan sifat masyarakat kecil hanya apatis, yang selalu tunduk dan taat pada penguasa, mudah dikelabui dengan janji-janji dan slogan-slogan yang menggiurkan, namun dalam kenyataannya hanyalah janji dan slogan kosong. Kisah berikut menggambarkan hal tersebut:

Seandainya ikan hiu adalah manusia, maka yang pertama akan dilakukan adalah membentuk moral ikan-ikan kecil. Ikan-ikan kecil harus rela berkorban, percaya dan patuh kepada ikan hiu, terutama jika kepada mereka dijanjikan masa depan yang cerah. (Wenn die Haifische Menschen wären, die Hauptsachen wäre natürlich die moralische Ausbildung der Fischlein. Sie werden unterrichtet werden, daß es der Grösste und Schönste sei, wenn ein Fischlein sich freudig aufopfert, und da $\beta$ sie alle an die Haifische glauben müßten, vor allem, wenn sie sagten, sie würden für eine schöne Zukunft sorgen).

Brecht secara lugas menggambarkan penguasa sebagai orang yang haus kekuasaan sehingga ia tidak segan-segan menjadikan masyarakat kecil sebagai pion yang sewaktu-waktu harus dikorbankan demi meraih kekuasaan yang ia 
idam-idamkan. Hal ini tampak pada cuplikan berikut:

Jika hiu adalah manusia, maka ia akan mengobarkan perang dengan menempatkan kelompok ikan kecil digaris depan untuk menguasai kelompok ikan kecil lainnya. (Wenn die Heischen Menschen wären, würden sie auch natürlich untereinander Kriege führen, um fremde Fischkästen und fremde Fischlein zu erobern).

Selanjutnya, pada bagian lain Brecht menggambarkan keadaan masyarakat kecil yang larut dalam kegembiraan dan keceriaan sesaat (semu) yang direkayasa oleh ikan hiu (penguasa) untuk menghibur dan menyenangkan hati masyarakat kecil (ikan-ikan kecil), namun yang terjadi pada akhirnya adalah menjerumuskan mereka ke dalam kekuasaan dan cengkraman (mulut) penguasa, sehingga sulit untuk melepaskan diri. Dalam hubungan ini, Brecht melukiskan keberadaan masyarakat yang mudah dipengaruhi dan mudah mempercayai janji-janji dan slogan-slogan moral penguasa. Hal ini dapat disimak dalam cuplikan teks berikut.

Andaikan ikan hiu adalah manusia, maka akan dihadirkan juga pentas seni. Taring ikan hiu akan diberi lukisan berwarna warni yang menunjukkan kemegahan, mulutnya dijadikan taman bermain, di mana selalu tergambar keceriaan. Teater disuguhkan dengan pelakonnya ikan-ikan kecil yang gagah berani, dengan bunyi musik yang begitu indah, sehingga semua ikan kecil turut menikmatinya (Wenn die Haifische Menschen wären, gäbe es bei ihnen natürlich auch eine Kunst. Es gäb schöne Bilder, auf denen die Zähne der Haifische in prächtigen Farben, ihre Rachen als reine Lustgarten, in denen es sich prächtig tummeln läßt, dargestellt wären. Die Theater auf dem Meeresgrund würden zeigen, wie heldenmütige Fischlein begeistert in die Haifischrachen schwimmen, und die Musik wäre so schön, dass die Fischlein unter ihren Klängen).

Brecht membeberkan kisah yang menggelitik, bahwa penguasa (ikan hiu) sok alim yang seolaholah sangat taat beragama, sehingga mampu melindungi dan menaungi masyarakat kecil (ikan-ikan kecil) dengan aman dan nyaman, namun ternyata sebenarnya hanyalah bentuk agama kamuflase yang dibuat untuk menutupi kebobrokan penguasa. Cuplikan teks berikut mengisahkan hal tersebut.

Andaikan ikan hiu adalah manusia, di sana pun ada agama. Ikan-ikan kecil diajarkan untuk tetap hidup dengan nyaman dalam lindungan ikan hiu (Auch eine Religion gäbe es da, wenn die Haifische Menschen wären. Sie würde lehren, dass die
Fischlein erst im Bauch der Haifische richtig zu leben begännen).

Pada bagian akhir kisah tersebut, Brecht pun masih membuat kisah yang menggelitik, dengan penilaian yang sangat positif bagi penguasa, karena mereka berbudaya, berbuat baik, berlaku jujur dan adil terhadap masyarakat kecil, namun sekaligus membeberkan dengan jelas sifat serakah yang berada di balik janji masa depan yang baik dan cerah tersebut, yang sebenarnya dimiliki penguasa. Sebab ternyata bahwa klimaks dari kisah tersebut adalah keuntungan bagi penguasa (ikan hiu), yang boleh memangsa ikan besar. Lewat cuplikan berikut terlihat jelas sifatsifat penguasa tersebut.

Andaikan ikan hiu adalah manusia, maka semua ikan kecil mendapat perlakuan yang sama. Ada yang beroleh jabatan dan boleh berkuasa atas ikan-ikan kecil lainnya. Yang agak besar boleh memangsa yang kecil-kecil, sedangkan hanya ikan hiu sendirilah yang boleh memangsa ikanikan besar..... Singkatnya, tentu ada budaya di laut, andaikan ikan hiu adalah manusia (Übrigens würde es auch aufhören, wenn die Haifische Menschen wären, dass alle Fischlein, wie es jetzt ist, gleich sind. Einige von ihnen würden Ämter bekommen und über die anderen gesetzt werden. Die ein wenig größeren dürfen sogar die kleineren auffressen. Das wäre für die Haifische nur angenehm, da sie dann selber öfter größere Brocken zu fressen bekämen. ......Kurz, es gäbe überhaupt erst eine Kultur im Meer, wenn die Haifische Menschen wären).

Secara gramatikal, keseluruhan kata kerja dan kata bantu kata kerja yang digunakan dalam anekdot tersebut disajikan dalam bentuk konyungtif, yang dalam Duden (Deutsches Universal Wörterbuch) menandai pengandaian artinya sesuatu keadaan yang tidak pasti atau tidak sebenarnya. Suatu keadaan yang tanpa jaminan, keadaan yang ireal (tidak nyata). Ini dapat diartikan bahwa janji ajaran moral, janji jaminan masa depan, janji kegembiraan dan keceriaan, janji gelar dan tanda jasa, janji ajaran agama, janji jabatan, dan sebagainya, yang digembar-gemborkan oleh penguasa adalah janji kosong alias kesia-siaan, atau yang dalam istilah hukum dikenal dengan pembohongan publik. Di sisi lain, masyarakat kecil pun dianggap bersalah, karena terlalu mudah dipengaruhi oleh/ penguasa dan mudah percaya pada slogan-slogan mereka.

Anekdote ini cukup menarik saat ini, karena mungkin makna yang tersirat di dalamnya tidak sesuai lagi dengan keadaan sosial politik bangsa Jerman saat ini, sebaliknya anekdote ini sangat 
sesuai dengan situasi politik di negera Indonesia tercinta. Para elit politik kita umumnya berusaha untuk mempengaruhi dan menyakinkan masyarakat dengan berbagai slogan moral, menjanjikan masa depan yang cerah dan lebih baik, melakukan yang terbaik yang semuanya demi rakyat. Pada kenyataannya yang terwujud hanyalah janji-janji kosong, karena mayoritas masyarakat bangsa ini masih berada dalam keterpurukan ekonomi, sosial dan politik, sementara para elit politik setelah terpilih hanya memperjuangkan kepentingan pribadi dan kelompok sendiri, sehingga hidup dalam kelimpahan dan kemewahan.

Di sisi lain, anekdote ini menarik, bukan hanya terletak pada cara pihak elit politik meyakinkan masyarakat dengan janji-janji dan slogan-logan moralnya yang kosong, melainkan pada mudahnya masyarakat mempercayai janji-janji tersebut. Fenomena inilah yang oleh Frans Magnis Suseno (1987:23, 44-45) disebut sebagai hilangnya etika sebagai sarana orientasi atau para penguasa (elit politik) dan masyarakat kecil tidak memiliki moral otonom, melainkan moral heteronom.

\section{Penutup}

Berdasarkan temuan dan pembahasan di atas, maka dapat disimpulkan bahwa Brecht dalam kisah anekdotnya: Seandanya Ikan Hiu adalah Manusia mengemukakan tiga hal penting yang terjadi sebagai cerminan atas kehidupan manusia saat itu dan yang terus terjadi sampai saat ini. Bahwa pada satu sisi para penguasa atau elit politik selalu memanfaatkan masyarakat untuk tujuan memperjuangkan kepentingan pribadi dan kelompoknya tanpa merasa bersalah. Dengan kata lain telah terjadi pembohongan publik yang menjadi trendnya para penguasa (elit politik), sedangkan pada sisi lain, masyarakat kecil sangat mudah dipengaruhi dan mengikuti apa yang disebut oleh Brecht dalam anekdotenya sebagai „ajaran moral“ yang diajarkan oleh para penguasa (elit politik). Dan yang terakhir, karakter para penguasa (elit politik) yang selalu membohongi masyarakat kecil dan ketidakberdayaan masyarakat kecil di mata para penguasa (elit politik), dipandang sebagai cerminan hilangnya etika sebagai sarana orientasi dan ketidakberdayaan mereka dalam menggunakan kebebasan eksistensionalnya.

\section{DAFTAR PUSTAKA}

Abidin, Zainal, 2003. Filsafat Manusia: Memahami Manusia melalui Filsafat. Bandung: Remaja Rosdakarya.

Baggini, Julian. 2003. Making Sense Filsafat dibalik Headline Berita. Diterjemahkan: Nurul Qamariah. Jakarta: Teraju.

Brecht, Berthold dalam Johanes Schuman. 1988. Deutsch für Mittelstife. München: Verlag für Deutsch.

Hardono, Hadi. 1996. Jati Diri Manusia. Yogyakarta: Kanisius.

Rutkowsky, Kurt. 1974. Das Studium der deutschen Literatur. Philadelphia: National Carls Schurs.

Santoso, Puji. 1993. Ancangan Semiotika dan Pengkajian Susastra. Bandung: Penerbit Angkasa.

Suseno, Magnis Franz. 1987. Etika Dasar, Masalah-Masalah Pokok Filsafat Moral. Yogyakarta: Kanisius.

Sutrisno, Mudji. 1995. Filsafat, Sastra dan Budaya, Jakarta: Penerbit Obor.

Toer, Pramoedya Ananta. 2003. Realisme Sosialis dan Sastra Indonesia, Jakarta: Penerbit Lentera Dipantara.

Watloly, Aholiab. 2001. Tanggung Jawab Pengetahuan. Yogyakarta: Kanisius. 